\title{
Toxicity of Neem's oil, a Potential Biocide against the Invasive Mussel Limnoperna fortunei (Dunker 1857)
}

\author{
PATRICIO J. PEREYRA ${ }^{1}$, GUSTAVO B. ROSSINI ${ }^{1}$ and GUSTAVO DARRIGRAN ${ }^{2}$ \\ ${ }^{1}$ División Zoología de Invertebrados, Facultad de Ciencias Naturales y Museo, Universidad Nacional de La Plata, \\ Paseo del Bosque no Lumber, (1900), La Plata, Argentina \\ ${ }^{2}$ Centro de Investigaciones Medio Ambientales, CIC-PBA 47 and 115, La Plata, Argentina \\ Manuscript received on May 13, 2011, accepted for publication on December 26, 2011
}

\begin{abstract}
The golden mussel Limnoperna fortunei (Dunker 1857) is one of the most distributed Nuisance Invasive Species (NIS) in South America, and a threat of great concern for the industry of the area. In this study, we carried out toxicity tests made with a Neem's oil solution with $L$. fortunei larvae and benthonic adults (7, 13 and $19 \pm 1 \mathrm{~mm}$ ). Tests with non-target species (Daphnia magna, Lactuca sativa and Cnesterodon decemmculatus) were also made with the aim to evaluate the potential toxicity of the Neem's solution in the environment. The $\mathrm{LC}_{100}$ of Neem's solution obtained for larvae was $500 \mu \mathrm{l} / \mathrm{L}$, a value much higher than the one obtained for D. magna and C. decemmaculatus. Thus, we recommend that it should not be used in open waters. However, since the adults were killed in $72 \mathrm{~h}$ and the larvae in $24 \mathrm{~h}$, this product can be used in closed systems, in man-made facilities.
\end{abstract}

Key words: biocide, impact, Limnoperna fortune, $i$ Neem's oil.

\section{INTRODUCTION}

Nuisance Invasive Species (NIS) are a major worldwide environmental problem (Mack et al. 2000, McGeoch et al. 2010), chiefly in freshwater systems (Sala et al. 2000, Strayer 2010). Bivalve mollusks are considered an aggressive NIS, both for their ability to affect the structure of the environment and the availability of resources in invaded ecosystems (i.e. ecosystems engineers, sensu Strayer et al. 1999), and their ability to infest man-made structures (Darrigran 2002, Darrigran and Damborenea 2005).

Correspondence to: Patricio Javier Pereyra

E-mail: pereyranis@gmail.com
The golden mussel Limnoperna fortunei (Bivalvia: Mytilidae) is one of the NIS most distributed in South America (Boltovskoy et al. 2006) and since its accidental introduction in 1991 (Pastorino et al. 1993) it has invaded streams and rivers in the Paraná basin, in at least four countries: Argentina, Brazil, Paraguay and Uruguay (Brugnoli et al. 2005, Darrigran 2002, Darrigran and Damborenea 2011, de Oliveira et al. 2006).

Limnoperna fortunei infests all types of man-made facilities: treatment plants, irrigation channels, reservoirs, hydroelectric power plants and fisheries (Darrigran 2010, Pestana et al. 2008, Rolla and Mota 2010). The most common strategy 
to fight this kind of trouble is the use of biocides (Mackie and Claudi 2010). The main advantage offered by this strategy is that it can be engineered to protect the entire facility, from the intake to the discharge, without altering the operability of the facility (Mackie and Claudi 2010).

Chlorine is the most used biocide, mainly because of its low cost, although its deleterious effects on the biota are well known (Mackie and Claudi 2010). Others treatments (e.g. ozone, sodium hydroxide) are starting to be used in manmade facilities in South America (Mackie and Claudi 2010). Now there is an increasing pressure to avoid the use of toxic substances against nontarget organisms (e.g. IMO 2007), and the current tendency is to find environmentally friendly biocides (Qian et al. 2010, Yebra et al. 2004).

Indian's Neem tree (Azadirachta indica A. Juss) is one of the most studied trees in the world (Girish and Shankara Bhat 2008), due to its enormous potential as a source of pesticides, insecticides and organic agrochemicals (Brahmachari 2004). The oil from its seeds is used as fungicide and insecticide (Girish and Shankara Bhat 2008), and its medical use has been recently recommended by the World Health Organization (WHO 2007). Its principal active component is Azadichtin (Figure 1) (Schaaf et al. 2000). Azadichtin has low toxicity against non-target organisms and low persistence in the environment (Schaaf et al. 2000), both of which are desirable characteristics for a biocide.

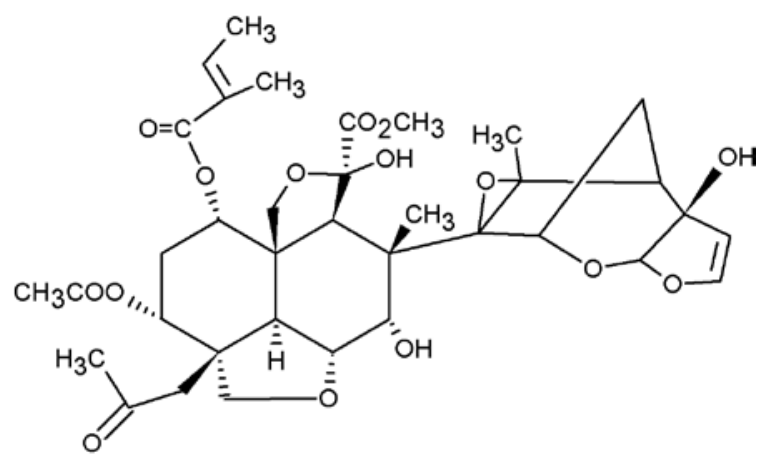

Figure 1 - Azaridachtin molecule.
Considering the problems caused by an infestation of $L$. fortunei in a man-made structure, and the potential of Neem's extracts, static bioassays have been proposed. With the aim to evaluate the acute toxicity of Neem's oil on $L$. fortunei, tests with three sizes of adults and the planktonic larvae were made. Also, tests with three non-target organisms, the cladocera Daphnia magna, the composite Lactuca sativa and the fish Cnesterodon decemmaculatus, were performed to evaluate the potential impact of Neem's oil in freshwater environments.

\section{METHODS}

Neem's solution consisted of a mix of $60 \%$ pure Neem's oil (Table I) and 40\% Fatty Ethoxylated Alcohol of 9 mols as emulsifier (Table II). Agenerator was used to prepare the solution (Integración Química S.R.L. pers. comm.).

All living organisms of $L$. fortunei were captured in the Argentinean coasts of the Río de la Plata $\left(34^{\circ} 49^{\prime} \mathrm{S}-57^{\circ} 56^{\prime} \mathrm{W}\right)$.

Adult mussels were collected manually and immediately transported to the GIMIP's laboratory (UNLP). Mussels were acclimated for 15 days in $10-\mathrm{L}$ aquaria (conductivity $=1 \pm 0.3 \mathrm{~ms} / \mathrm{cm}$, temperature $=23 \pm 2{ }^{\circ} \mathrm{C}$, and $\mathrm{pH}=7 \pm 0.5$ ). The water was completely replaced the first three days and then partially replaced $(5 \mathrm{~L})$ every two days until the end of the 15-day acclimation period. The mussels were fed with fish food $\left(\right.$ TetraMin $\left.^{\circledR}\right)$ daily, except for the last two days (Pereyra et al. 2011).

Larvae were collected by filtering $1000 \mathrm{~L}$ of water throughout a $45-\mu \mathrm{m}$ mesh plankton net. The samples were immediately transported to the lab, where the existence of enough larvae for each assay was checked.

Neonates of D. magna were obtained from cultures maintained in the laboratory (CIMA UNLP) under standard conditions (conductivity $=1.0 \mathrm{~ms} / \mathrm{cm}$; hardness $=215 \mathrm{mg} / \mathrm{L}$ de $\mathrm{CO} 3 \mathrm{Ca}$; alkalinity $=180 \mathrm{mg} / \mathrm{L}$ de $\mathrm{CO} 3 \mathrm{Ca} ; \mathrm{pH}$ range $7.6 \pm$ 
TABLE I

Neem's oil characteristics

(Integración Química S.R.L. pers. comm.).

\begin{tabular}{ll}
\hline & Physical and chemical properties \\
\hline Physical state & Liquid \\
Appearence & Brown viscous liquid \\
Ph & $7 \pm 0.02$ \\
Boiling point & above $100^{\circ} \mathrm{C}$ \\
Freezing point & $14^{\circ} \mathrm{C}$ \\
Auto Ignition temperature & above $200^{\circ} \mathrm{C}$ \\
Flash point & above $170^{\circ} \mathrm{C}-$ No fire Hazard \\
Decomposition temperature & None \\
Solubility in water & Emulsifies with water \\
Molecular formula & Not applicable \\
Molecular Weight & Not applicable \\
\hline & Stability and reactivity \\
\hline Chemical stability & $\begin{array}{l}\text { Stable at ordinary condition } \\
\text { of use and storage }\end{array}$ \\
Conditions to avoid & No restriction \\
Hazardous decomposition & None \\
products & None \\
Hazardous polymerization & Not irritant \\
Primary eye irritation & Not irritant \\
Skimary skin irritation & Non sensitizer \\
\hline
\end{tabular}

TABLE II

Characteristics of Fatty Ethoxilate Alcohol (Integración Química S.R.L. pers. comm.).

\begin{tabular}{ll}
\hline $\begin{array}{l}\text { Physical and chemical } \\
\text { properties }\end{array}$ & \\
\hline Physical estate & Pasty \\
Color & White \\
Boiling point & $300^{\circ} \mathrm{C}$ \\
Fusion point & $25^{\circ} \mathrm{C}$ \\
Inflammation point & $175^{\circ} \mathrm{C}$ \\
Auto ignition point & $500^{\circ} \mathrm{C}$ \\
Solubility in water & Soluble \\
Ph & 7.0 \\
\hline Stability and reactivity & \\
\hline Conditions to avoid & Unknown \\
Hazardous decomposition & None \\
products & $>300^{\circ} \mathrm{C}$ \\
Thermal decomposition & Biodegradable \\
Biodegradability &
\end{tabular}

0.2 ; temperature $20 \pm 2{ }^{\circ} \mathrm{C}$; photoperiod 16:8 light: darkness), and fed with chlorococcal algae.

Seeds of L. sativa (mantecosa variety) were obtained from commercial suppliers, with $98 \%$ of guaranteed germination.

Individuals of $C$. decemmaculatus were caught in streams of the zone, in fields with low or null utilization of agrochemicals. These individuals were transported to the laboratory (CIMA - UNLP) and held in 1200 L plastic pools (Pelopincho ${ }^{\circledR}$ ), where they were daily fed with TetraMin ${ }^{\circledR}$ fish food. For the toxicity test, juveniles born in the laboratory were used.

Limnoperna fortunei tests were made with larvae and three sizes of adults (7,13 and 19 $\pm 1 \mathrm{~mm})$. Every test was made in triplicate, using at least five concentrations and one control. Dechlorinated tap water was used for the dilutions. Temperature (mean $\left.=23{ }^{\circ} \mathrm{C}, \min =21.2{ }^{\circ} \mathrm{C}, \max =24.3^{\circ} \mathrm{C}\right)$, photoperiod (16:8 light: darkness), $\mathrm{pH}$ (mean $=7.07, \min =6.19$, $\max =7.48)$ and conductivity $(0.75 \pm 0.3 \mathrm{~ms} / \mathrm{cm})$ were controlled.

Tests with adults were performed choosing individuals by size with a digital caliber $(0.01 \mathrm{~mm}$ precision) $24 \mathrm{~h}$ before each assay. Twelve mussels were placed on plastic Petri dishes and held in plastic containers with $500 \mathrm{ml}$ of dechlorinated tap water and artificial aeration. After $24 \mathrm{~h}$, the plastic Petri dishes with the mussels attached by byssal threads were transferred to other plastic containers with $500 \mathrm{ml}$ of Neem's solution. Mussels that had not attached to the Petri dish after the first $24 \mathrm{~h}$ were considered unapt for the assay and thus discarded (Pereyra et al. 2011). Mortality was checked after $72 \mathrm{~h}$. Failure to respond to external tactile stimuli was used as the death criterion.

The assays with larvae were made with $12 \mathrm{ml}$ of Neem's solution and adding 10 to 15 larvae in every plastic Petri dish. Mortality was checked after $24 \mathrm{~h}$ under a stereoscopic magnifying glass. A larva was considered dead if it was not swimming or if there were no signs of internal activity (by transparency) (Pereyra et al. 2011). 
International standardized methods (USEPA 1996a, b, c) for all non-target species were used in these tests. All tests were made with at least five concentrations and one control.

For the tests with D. magna, individuals were exposed to the toxic for $48 \mathrm{~h}$ with dechlorinated tap water for solutions (conductivity $=1.05 \mathrm{~ms} /$ $\mathrm{cm}$; hardness $=215 \mathrm{mg} / \mathrm{L}$ de $\mathrm{CO}_{3} \mathrm{Ca}$; alkalinity 180 $\mathrm{mg} / \mathrm{L}$ de $\mathrm{CO}_{3} \mathrm{Ca}, \mathrm{pH}$ range $7.5 \pm 0.2$ ). The tests were carried under controlled conditions (temperature $20 \pm 2{ }^{\circ} \mathrm{C}$; photoperiod $=16: 8$ light: darkness), and without feeding the neonates. Ten neonates were placed in every test tube with $10 \mathrm{ml}$ of solution each. Mortality was checked 48 hours later. A neonate was considered dead when it remained at the bottom of the test tube and showed no signs of activity.

For the tests with L. sativa, plants were exposed to the toxic for $120 \mathrm{~h}$ in darkness and controlled temperature $\left(22 \pm 2{ }^{\circ} \mathrm{C}\right)$. Double distilled water was used as dilution water. Twenty seeds were placed into plastic Petri dishes containing a sterilized filter paper with $3 \mathrm{ml}$ of solution to be tested for every dish. Plastic Petri dishes were placed in darkness for $120 \mathrm{~h}$, and germination and elongation of the roots were evaluated at the end of the test.

For the tests with $C$. desemmaculatus, individuals were exposed to the toxic for $96 \mathrm{~h}$ (USEPA 1996c). Five juveniles were held in plastic containers with $500 \mathrm{ml}$ of solution each. Juveniles were kept without aeration or feeding. Solutions were replaced daily until completing $96 \mathrm{~h}$ of exposure to the toxic. A juvenile was considered dead when it remained at the bottom of the plastic container showing no signs of activity.

For L. fortunei, the $\mathrm{LC}_{50}$ were calculated using linear regression, previous transformation of the concentration with logarithm and the mortality to probit units (Finney 1978), using USEPA program Probit 1.5 . The lowest concentration that effectively caused $100 \%$ mortality in exposed organisms was considered as $\mathrm{LC}_{100}$.

For D. magna and C. desemmaculatus, all the estimations of the $\mathrm{LC}_{\mathrm{XX}}$ were made with the probit program, considering the $\mathrm{LC}_{1}$ as NOEC (the highest concentration of the product at which no significant differences as regards the control were seen), and the $\mathrm{LC}_{10}$ as LOEC (the lowest concentration of the product at which a significant difference as regards the control was seen).

For L. sativa, the $\mathrm{IC}_{50}$ (Inhibition concentration 50 , i.e., the concentration at which $50 \%$ of inhibition as regards the control is observed) was obtained using linear regression with the logarithmic transformation of the concentrations, using the inhibition proportion concerning the control as the dependent variable. The NOEC and LOEC were calculated with a posteriori comparisons of Dunnet, previous ANOVA.

\section{RESULTS and DISCUSSION}

Table III shows the results obtained for $L$. fortunei, Table IV shows those for D. magna and $C$. decemmaculatus, and Table $\mathrm{V}$ shows those for $L$. sativa. The $\mathrm{LC}_{100}$ of $L$. fortunei larvae was 500 $\mu \mathrm{l} / \mathrm{L}$. The $\mathrm{LC}_{100}$ of adults could not be estimated because the concentrations tested did not achieve $100 \%$ mortality.

This results show i) Neem's oil has acute toxicity against $L$. fortunei, and ii) the larvae are more vulnerable to the toxic than the adults. This agrees with what was previously reported about the vulnerability of the initial stages of development (Maroñas and Damborenea 2006, Van Benschoten et al. 1995) and with previous assays made with other organic biocides against L. fortunei (Pereyra et al. 2011).

TABLE III

$\mathrm{LC}_{\mathbf{5 0}}$ and confidence intervals (CI) for all stages of

Limnoperna fortunei with Neem's oil solution. All concentrations are expressed in $\mu \mathrm{l} / \mathrm{L}$.

\begin{tabular}{cccc}
\hline & & \multicolumn{2}{c}{ CI } \\
\cline { 3 - 4 } & $\mathrm{CL}_{50}$ & Superior & Inferior \\
\hline Larvae & 8 & 315 & 2 \\
$7 \pm 1 \mathrm{~mm}$ & 241 & 315 & 171 \\
$13 \pm 1 \mathrm{~mm}$ & 249 & 827 & 101 \\
$19 \pm 1 \mathrm{~mm}$ & 122 & 153 & 98 \\
\hline
\end{tabular}


TABLE IV

$\mathrm{LC}_{50}$, NOEC, LOEC and respective confidence intervals of Daphnia magna y Cnesterodon decemmaculatus. All concentrations are expressed in $\mu \mathrm{l} / \mathrm{L}$.

\begin{tabular}{lcccccccc}
\hline \multicolumn{2}{l}{ Daphnia magna } \\
\hline $\mathrm{CL}_{50}$ & Limit inferior & Limit superior & NOEC & Limit inferior & Limit superior & LOEC & Limit inferior & Limit superior \\
\hline 17 & 11.35 & 35.58 & 1.65 & 0.12 & 3.18 & 4.71 & 1.77 & 6.69 \\
\hline \multicolumn{2}{l}{ Cnesterodon decemmaculatus } \\
\hline $\mathrm{CL}_{50}$ & Limit inferior & Limit superior & NOEC & Limit inferior & Limit superior & LOEC & Limit inferior & Limit superior \\
\hline 4.92 & 4.01 & 6.09 & 2.08 & 0.97 & 2.83 & 3.06 & 1.92 & 3.8 \\
\hline
\end{tabular}

As mentioned in the introduction, chlorine is the most widespread biocide used in man-made facilities (Mackie and Claudi 2010). Chlorine shows $100 \%$ mortality at $576 \mathrm{~h}$, with $1.2 \mathrm{mg} / \mathrm{L}$ (Morton et al. 1976), and at $408 \mathrm{~h}$ with $1 \mathrm{mg} / \mathrm{L}$ at 25 ${ }^{\circ} \mathrm{C}$ (Cataldo et al. 2003). Similar results have been observed with other three macrofouler bivalves: Dreissena polymorpha, Mytilus edulis and Perna viridis (see discussion in Pereyra et al. 2011). Working with tannins of Schinopsis balansae (Englers.), we have previously obtained the $\mathrm{LC}_{50}$ of L. fortunei, for adult mussels of 13 and $19 \pm 1 \mathrm{~mm}$, after $168 \mathrm{~h}$ of exposure to the toxic (Pereyra et al. 2011). In this study, although $100 \%$ mortality was not achieved (the maximum mortality reached was $80 \%$, data not shown), a considerable reduction in the exposure time to the toxic was obtained.

Results show no overlap between the $\mathrm{LC}_{50}$ of L. fortunei (both stages) and L. sativa (Tables III and $\mathrm{V})$, indicating that at these concentrations Neem's oil has no effect on $L$. sativa. There is overlapping between the $\mathrm{LC}_{50}$ of $L$. fortunei and those achieved with D. magna and C. desemmaculatus (Tables III and IV). In view of these results, we recommend not to use this product in open waters. Likewise, this product is recommended to be used in closed systems in man-made facilities.

It is important to note that the use of biocides to control macrofouling is one of the treatments to apply. The treatment to be used depends on the possibility of each section of the facilitie, the time of the year and the stages to control (Costa et al. 2008,
Darrigran et al. 2007). Other techniques (e.g. ozone) are used to prevent macrofouling of bivalves, but are difficult to apply and expensive (Mackie and Claudi 2010). Using products like Neem's oil is a valid alternative in closed systems.

TABLE V

$\mathrm{IC}_{\mathbf{5 0}}$, and confidence intervals of Lactuca sativa. All concentrations are expressed in $\mu \mathrm{l} / \mathrm{L}$.

\begin{tabular}{cc}
\hline \multicolumn{2}{c}{ Neem's oil } \\
\hline $\mathrm{IC}_{50}$ & 3,020 \\
$\mathrm{~L}_{\text {sup }}$ & 12,081 \\
$\mathrm{~L}_{\text {inf }}$ & 750 \\
\hline $\mathrm{NOEC}$ & 250 \\
$\mathrm{LOEC}$ & 500 \\
\hline
\end{tabular}

Another emerging perspective is that combined techniques (e.g. Costa et al. 2011) can be applied to improve the control measures in man-made facilities.

Finally, the bioassays with biocides with $L$. fortunei carried out to date have been made in static conditions (e.g. Cataldo et al. 2003, Darrigran and Damborenea 2001, Pereyra et al. 2011). These kinds of assays have the advantage of their practicality and low impact, but the results should be tested in the industry. For example, Rolla and Mota (2010) have reported that the reduction in the spread of $L$. fortunei in the Paraíba River resulted, in part, from the elimination of the golden mussel from the transitory harbors with the use of chlorine. However, there are no reports on the effects of chlorine over the biota (Rolla and Mota 2010). This lack of communication between scientists 
and the people involved (e.g. stakeholders, the company, the community) has been observed in other areas of NIS control (e.g. Donlan et al. 2003, Gardener et al. 2010, Shanley and López 2009), and represents another problem to be solved in order to achieve effective control programs of the golden mussel.

\section{RESUMO}

\section{O Mexilhão dourado Limnoperna fortunei (Dunker} 1857) é uma das espécies invasoras melhor distribuídas na América do Sul, sendo motivo de grande preocupação para a indústria local. Neste estudo, nós realizamos ensaios de toxicidade de soluções de Óleo de Neem em larvas e adultos bentônicos de L. fortune (7, 13 e $19 \pm 1 \mathrm{~mm}$ ). Com o objetivo de avaliar o potencial tóxico do Óleo de Neem no ambiente também foram realizados testes com organismos não alvo (Daphnia magna, Lactuca sativa e Cnesterodon decemmculatus). $\mathrm{A} \mathrm{LC}_{100}$ da solução de Neem para larvas foi $500 \mu \mathrm{l} / \mathrm{L}$, um valor muito superior ao obtido para D. magna e C. decemmaculatus. Desta forma, nossa recomendação é que este óleo não deve ser utilizado em ambientes naturais abertos. No entanto, uma vez que os adultos morreram em $72 \mathrm{~h}$ e as larvas em $24 \mathrm{~h}$, este produto pode ser utilizado em sistemas fechados construídos pelo homem.

Palavras-chave: biodia, impacto, Limnoperna fortune, óleo de Neem.

\section{REFERENCES}

Boltovskoy D, Correa N, Cataldo D ANd Sylvester F. 2006. Dispersion and ecological impact of the invasive freshwater bivalve Limnoperna fortunei in the Río de la Plata Watershed and Beyond. Biolog Invas 8: 947-963.

BRAHMACHARI G. 2004. Neem - a omnipotent plant: a retrospection. Chem Biochem 5: 408-421.

Brugnoli E, Clemente J and Boccardi L. 2005. Golden mussel Limnoperna fortunei (Bivalvia: Mytilidae) distribution in the main hydrographical basins of Uruguay: update and predictions. An Acad Bras Cienc 77: 235-244.

Cataldo D, Boltovskoy D And Pose M. 2003. Toxicity of chlorine and three nonoxidizing molluscides to the pest mussel Limnoperna fortunei. J AWWA 95: 66-78.

Costa R, ALdRIDGE DC AND MogGrIDGE GD. 2008. Seasonal variation of zebra mussel susceptibility to molluscicidal agents. J Appl Ecol 45: 1712-1721.
Costa R, Elliot P, Aldridge DC and Moggridge GD. 2011. Enhanced mortality of the biofouling zebra mussel, Dreissena polymorpha, through the application of combined control agents. J Great Lakes Res 37: 272-278.

DARRIGRAN G. 2002. Potential impact of filter-feeding invaders on temperate inland freshwater environments. Biolog Invas 4: 145-156.

DARRIGRAN G. 2010. Summary of the distribution and impact of the golden mussel in Argentina and neighboring countries. In: MONITORING AND CONTROL OF MACROFOULING MOLLUSKS IN FRESH WATER SYSTEMS, Boca Raton: Taylor and Francis Group, Boca Raton. Mackie GL and Claudi R, p. 389-396.

DARRIGRAN G AND DAMBORENEA C. 2001. Concentraciones letales de un biocida para adultos del molusco invasor Limnoperna fortunei (Mytilidae). Paper presented at Actas Seminario Internacional sobre Gestión Ambiental e Hidroelectricidad. Salto Grande, Argentina.

DARRIGRAN G AND DAMBORENEA C. 2005. A bioinvasion history in South America. Limnoperna fortunei (Dunker, 1857), the golden mussel. Am Malacol Bull 20: 105-112.

DARRIGRAN G AND DAMBORENEA C. 2011. Ecosystem engineering impact of Limnoperna fortunei in South America. Zool Sci 28: 1-7.

DARrigran G, DAMBORENEA C AND GRECO N. 2007. Freshwater invasive bivalves in man-made environments: A case study of larvae biology of Limnoperna fortunei in a Hydroelectric Power Plant in South America. AMBIO 36: 575-579.

De OliVeIra MD, TAKedA AM, De BARros LF, BARbosa DS AND DE RESENDE EK. 2006. Invasion by Limnoperna fortunei (Dunker, 1857) (Bivalvia, Mytilidae) of the Pantanal Wetland, Brazil. Biolog Invas 8: 97-104.

Donlan CJ, THERShy BR, CAMPBELl K AND CRUZ F. 2003. Research for requiems: the need for more collaborative action in eradication of invasive species. Conserv Biol 17: $1850-1851$.

FINNEY DL. 1978. Statistical method in biological assay. Third edition. Charles Griffin and Company Ltd. London and High Wycombe, UK.

GARDENER MR, AtKINSON R AND RENTERÍA JL. 2010. Eradication and people: lessons from the plant eradication program in Galapagos. Rest Ecol 18: 20-29.

GIRISH K AND SHANKARA BHAT S. 2008. Neem - A Green Treasure. Elect J Biol 4: 102-111.

IMO - INTERNATIONAL MARITIME ORgANIZATION. 2007. International convention on the control of harmful antifouling systems on ships, 2001 [Internet]. 2007 Sep 17. Available from: http://www.imo.org/includes/blastDataOnly. asp/data_id\%3D20019/14.pdf

Mack RN, Simberloff D, Lonsdale WM, Evans H, Clout M AND BAZZAZ F. 2000. Biotic invasions: causes, epidemiology, global consequences and control. Ecol Appl 5:1-22.

MACKIE GL AND ClaUdi R. 2010. Monitoring and control of macrofouling mollusks in fresh water systems. Boca Raton: Taylor \& Francis Group, Boca Raton, London, New York, $552 \mathrm{p}$. 
MAROÑAS ME AND DAMBORENEA C. 2006. Efectos de biocidas y tolerancia a la exposición al aire. In Darrigran $\mathrm{G}$ and Damborenea C (Eds), BIO-INVASIÓN DEL MEJILLÓN DORADO EN EL CONTINENTE AMERICANO, La Plata: Edulp, La Plata, Argentina. Darrigran G and Damborenea C, p. 167-179.

McGeoch MA, Butchart SHM, Spear D, Marais E, Kleynhans EJ, Symes A And Chanson J. 2010. Global indicators of biological invasion: species numbers, biodiversity impact and policy responses. Div Dist 16: 95-108.

Morton B, AU CS AND LAM WW. 1976. Control of Limnoperna fortunei. J Inst Wat Eng Scient 30: 147-156.

PASTORINO G, DARRIGRAN GA, MARTín SM AND LUNASCHI L. 1993. Limnoperna fortunei (Dunker 1857) (Mytilidae), nuevo bivalvo invasor en aguas del rio de la plata. Neotropica 39: 101-102.

Pereyra PJ, Bulus Rossini G and Darrigran G. 2011. Toxicity of three commercial tannins to the nuisance invasive species Limnoperna fortunei (Dunker, 1857): implications for control. Fres Env Bull 20: 1432-1437.

Pestana D, Pie Mr, Ostrensky A, Boeger WA, Andreoli C, Franceschi F AND LAgos P. 2008. Seasonal Variation in Larval Density of Limnoperna fortunei (Bivalvia, Mytilidae) in the Iguaçu and Paraná Rivers, in the region of Foz do Iguaçu, Paraná, Southern Brazil. Braz Arch Biol Techn 51: 607-612.

QIAN PY, XU Y AND FUSETANI N. 2010. Natural products as antifouling compounds: recent progress and future perspectives. Biofouling 26: 223-234.

Rolla ME AND MOTA HR. 2010. Response of a major Brazilian utility to the golden mussel invasion. In: MONITORING AND CONTROL OF MACROFOULING MOLLUSKS IN FRESH WATER SYSTEMS. Boca Raton: Taylor and Francis Group, Boca Raton. Mackie GL and Claudi R, p. 396-403.

SALA OE ET AL. 2000. Global biodiversity scenarios for the year 2100. Science 287: 1770-1774.
SchaAF O, JARVIS AP, VAN DER Esch SA, Giagnacovo G AND OLDHAM NJ. 2000. Rapid and sensitive analysis of azadirachtin and related triterpenoids from Neem (Azadirachta indica) by high-performance liquid chromatography-atmospheric pressure chemical ionization mass spectrometry. J Chromat A 886: 89-97.

SHANLEY P AND LÓPEZ C. 2009. Out of the loop: why research rarely reaches policy makers and the public and what can be done. Biotropica 41: 535-544.

STRAYER DL. 2010. Alien species in fresh waters: ecological effects, interactions with other stressors and prospects for the future. Fresh Biol 55: 152-174.

Strayer DL, CARaco NF, Cole JJ, Findlay S And Pace ML. 1999. Transformation of freshwater ecosystems by bivalves. Bioscience 49: 19-27.

USEPA - U.S. ENVIRONMENTAL PRotection AgENCY. 1996a. Ecological effects test guidelines OPPTS 850.1010 Aquatic invertebrate acute toxicity test, freshwater daphnids, 712-C-96-114.

USEPA - U.S. ENVIRONMENTAL PROTECTION AGENCY. 1996b. Ecological effects test guidelines OPPTS 850.4200 Seed germination/root elongation toxicity test, 712-C-96-154.

USEPA - U.S. ENVIRONMENTAL PROTECTION AgENCY. 1996c. Ecological Effects Test Guidelines OPPTS 850.1075 Fish Acute Toxicity Test, Freshwater and Marine, 712-C-96-118.

VAN BENSChoten JE, JeNSEN JN, HARRINGTON DK AND DEGIROLAMO D. 1995. Zebra mussel mortality with chlorine. J AWWA 87: 101-108.

WHO. 2007. WHO monographs on selected medicinal plants. Zhang X (Coord), Vol 3, World Health Organization, Geneva, Sweden.

Yebra DM, Søren K AND DAM-Johansen K. 2004. Antifouling technology- past, present and future steps towards efficient and environmentally friendly antifouling coatings. Prog Org Coat 50: 75-104. 